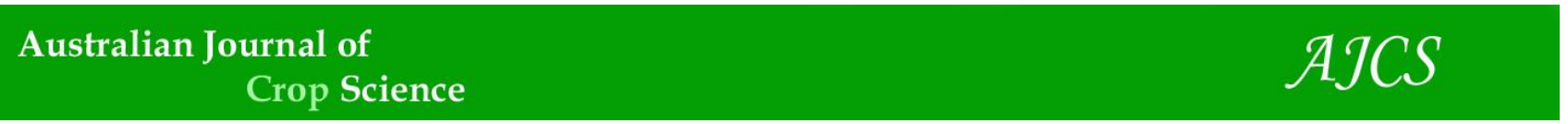

AJCS 14(05):842-851 (2020)

ISSN:1835-2707

\title{
Nitrogen fertilization management in common bean and castor bean intercropping systems
}

\author{
Gisele C. Silva ${ }^{1}$, Marcos Eduardo V. Araujo ${ }^{2}$, Veridiana F.R. Almeida ${ }^{1}$, Rodrigo S.L. Araújo ${ }^{1}$, Amanda \\ Cristina E. Lourenço ${ }^{1}$, Cristiane F. Lisboa ${ }^{2}$, Itamar R. Teixeira ${ }^{1,{ }^{*}}$, Maryelle B. Silva ${ }^{3}$, Westefann S. Sousa ${ }^{3}$, \\ Alessandro G. Silva ${ }^{4}$
}

${ }^{1}$ State University of Goiás, Department of Agricultural Engineering, BR-153, 3105 - Fazenda Barreiro do Meio, Anápolis, Goiás, 75132-400, Brazil

${ }^{2}$ Federal University of Viçosa, Department of Agricultural Engineering, Avenida Peter Henry Rolfs, s/n - Campus Universitário, Viçosa, Minas Gerais, 36570-900, Brazil

${ }^{3}$ State University of Goiás, Department of Agronomy, Vila Dona Nilza, SetorUniversitário, Ipameri, Goiás, 75780-000, Brazil

${ }^{4}$ University of Rio Verde, Department of Agronomy, Fazenda Fontes do Saber Campus Universitário, Rio Verde, Goiás, 75901-970, Brazil.

\section{*Corresponding author: itamar.texeira@ueg.br}

\section{Abstract}

The objective of this work was to evaluate the nutrition and agronomic characteristics of common bean and castor bean under intercropping subject of nitrogen fertilization in top dressing. A randomized block design in a $2 \times 2 \times 4+4$ factorial scheme was used, and there were three replicates. The treatments consisted of two common bean cultivars (Pontal and Pérola), which were intercropped with two castor bean cultivars (Energia and Paraguaçu), and combined with four nitrogen treatments ( $0,50,100$ and $200 \mathrm{~kg} \mathrm{ha}^{-1}$ ). Four additional treatments involved bean and castor bean cultivars at a single dosage of $40 \mathrm{~kg} \mathrm{ha}^{-1}$ nitrogen. The nitrogen, potassium, calcium, magnesium and sulfur contents in castor bean intercropped with common bean leaves were influenced by nitrogen treatments. For common bean applied as top dressing, the maximum grain yields were 1,122 and 1,024 kg $\mathrm{ha}^{-1}$ for cultivars (cvs.) Pontal and Pérola, respectively, with a dose of $100 \mathrm{~kg} \mathrm{ha}^{-1}$ nitrogen. Similar results were observed for castor bean, for whom $100 \mathrm{~kg} \mathrm{ha}^{-1}$ nitrogen provided the largest number of bunches and number of berries per bunch and the highest grain yield. The maximum values observed were 38 and 27 bunches per plant, 27.6 and 35.4 berries per bunch and 1,474 and 1,286 $\mathrm{kg} \mathrm{ha}^{-1}$ grain yield for cvs. Paraguaçu and Energia, respectively.

Keywords: Crop association, fertilization, Phaseolus vulgaris, production, Ricinus communis.

Abbreviations: Eq_equation; CV_cultivar; Cvs_cultivars; IAC_Institute Agronomic of Campinas; DAE_days after emergence.

Introduction

The efficiency of intercropped crops depends on the complementarity of the crops involved (Gebru, 2015). Thus, the cultivation of castor bean, which is of great importance worldwide given the diversity of products derived from its grains (Campos and Santos, 2015; Mohamed and Mursy, 2015) and is designated by the Federal Government of Brazil as the first choice for projects related to the production of biodiesel fuel (Monteiro et al., 2013; Goneli et al., 2018), is mainly performed in combination with short-cycle crops such as the common bean, the main protein source of the classes with a lower purchasing power, as good options for farmers.

Fertilization, especially with nitrogen, phosphorus and potassium macronutrients, is of fundamental importance for obtaining high yields. Nitrogen is an essential nutrient that is required by plants in great quantities. It represents from 2 to $6 \%$ of the dry mass of plants. A correct dose of nitrogen increases growth and produces dark green leaves due to the abundance of chlorophyll (Marschner, 2012). Nitrogen is a nutrient with high mobility in the soil-plant-atmosphere system, and it is easily lost through volatilization or leaching. Moreover, nitrogen fertilizers have low efficiency and are expensive to synthesize, and in addition to raising the cost of the final product, nitrogen fertilization can contaminate the environment (Trenkel, 2010; Fan and Li, 2010).

Nitrogen, which can be considered one of the chemical bases of life, is an integral part of proteins, amino acids, albuminoids, chlorophyll, and enzymes (Marschner, 2012). Under certain circumstances, excessive amounts of nitrogen can prolong the growth period, producing lush vegetation, delaying maturity, and creating soft tissues without resistance to pests and diseases, especially when the supply of other elements is inadequate (Huber and Thompson, 2007). On the other hand, in its absence, weak vegetation is produced, characterized by few vegetative organs and yellowish green leaves (Mengell e Kirkby, 2001). 
Research has generally paid good attention to nitrogen fertilization in castor bean crops (Lange et al., 2005; Severino et al., 2006a,b; Silva et al., 2007; Lima et al., 2008; Moro et al., 2011; Ferreira et al., 2014, Mateus et al., 2015). However, most studies have included few of the genotypes commonly used by producers, those mostly recommended for Northeast Brazil. For the Midwest region, where the castor bean crop is emerging, there is still no research, and in some situations, the recommendations forsingle-crop fertilizers vary widely, and there is no real knowledge of crop requirements under the edaphoclimatic conditions predominant in the region concerned.

Regarding common beans, monoculture cultivation has become highly profitable, acquiring the status of entrepreneurial culture employing advanced technologies and leading to productivity levels of approximately $3000 \mathrm{~kg}$ $\mathrm{ha}^{-1}$, similar to those in the Midwest region in States Goiás and Distrito Federal in the third cropping, called autumnwinter (Conab, 2019). However, there are few studies on mineral nutrition under intercropping (Cardoso et al., 2013; Cunha et al., 2014; Ferreira et al., 2014).

Only knowledge of the real nutritional requirements of plants in intercropping systems will provide high levels of productivity. Therefore, studies should evaluate the response of castor beans intercropped with common bean as a function of nitrogen fertilization, aiming to provide relevant information to technicians and producers, with a particular emphasis on small family properties (Lange et al., 2005; Ferreira et al., 2014).

Thus, the objective of this work was to evaluate the effect of the application of different doses of nitrogen on the nutrition and yield of castor beans intercropped with bean cultivars.

\section{Results and Discussion}

\section{Plant nutrition of common bean and castor bean}

Table 1 shows the coefficients of the linear and nonlinear regression models used to describe the analyzed quantitative variables that presented a significant difference $(p<0.05)$. For the studied variables, the linear (Eq. 1) and quadratic (Eq. 2) models presented the best fit to the data, with satisfactory determination coefficients.

$$
Y=\beta_{0}+\beta_{1} N
$$

$$
Y=\beta_{0}+\beta_{1} N+\beta_{2} N^{2}
$$

Where $Y$ is the characteristic evaluated, $N$ is the dose of nitrogen $\left(\mathrm{kg} \mathrm{ha}^{-1}\right), \beta_{0}$ is the regression constant and $\beta_{1}$ and $\beta_{2}$ are the regression coefficients.

The nitrogen content in leaf tissue increased with increasing nitrogen fertilization, with a maximum value of $38.4 \mathrm{~g} \mathrm{~kg}^{-1}$ at $100 \mathrm{~kg} \mathrm{ha}^{-1}$ and a minimum value of $35 \mathrm{~g} \mathrm{~kg}^{-1}$ in the control treatment (Fig 1), regardless of the culture studied. This behavior is justified by the interference of nitrogen fertilization applied in cover and absorbed by the plant. Andrade et al. (2004) found higher levels of nitrogen in the leaf dry mass of the cultivars Pérola and Aporé ( 36 and $37 \mathrm{~g}$ $\mathrm{kg}^{-1}$, respectively), close to the values obtained in the present work. The average foliar nitrogen content is within the range considered to be adequate for this common bean
(Martinez et al., 1999) at full flowering (between 30-35 g kg $\left.{ }^{1}\right)$.

The potassium leaf content varied among intercropped bean cultivars. The cv. Pontal showed decreases in potassium content as a function of the increase in nitrogen coverage, obtaining a maximum content of $18.8 \mathrm{~g} \mathrm{~kg}^{-1}$ at a dose of 50 $\mathrm{kg} \mathrm{ha}^{-1}$ of nitrogen coverage. On the other hand, a minimum leaf potassium content of $17.4 \mathrm{~g} \mathrm{~kg}^{-1}$ was obtained in the control treatment (Fig 2A). The application of fertilization at doses above 200 ha $^{-1}$ nitrogen cover promoted a decrease in the potassium content in bean leaves of $\mathrm{cv}$. Pontal under intercropping with castor bean, demonstrating a certain antagonism between nitrogen and potassium. Additionally, cv. Pérola showed beneficial effects of increased nitrogen fertilization under crop cover, reaching a maximum of $18.1 \mathrm{~g}$ $\mathrm{kg}^{-1}$ at a dose of $100 \mathrm{~kg} \mathrm{ha}^{-1}$ nitrogen and a minimum value of $17.1 \mathrm{~g} \mathrm{~kg}^{-1}$ in the control treatment. Based on the parameters described by Martinez et al. (1999), who established adequate potassium levels found in bean leaves in full bloom ranging from $27-35 \mathrm{~g} \mathrm{~kg}^{-1}$, it can be noted that the values found in both common bean cultivars intercropped with castor bean, Pontal and Pérola, were below the values considered adequate; however, nodeficiency symptoms during growth were observed.

The calcium content behaved similarly to the potassium leaf content in bean plants intercropped with castor bean, except that it decreased for $\mathrm{Cv}$. Pérola and increased up to a dose of $100 \mathrm{~kg} \mathrm{ha}^{-1}$ for cv. Pontal (Fig 2B). This behavior is due to the occurrence of the "dilution" effect since the addition of nitrogen promoted an increase in dry biomass produced by common bean and, as a result, decreased the calcium content in plant tissues (Marschner, 2012). However, the decrease in calcium content in plant tissues did not compromise growth/development.

The magnesium content behaved similarly to the potassium and calcium leaf contents in the leaves of castor beans intercropped with bean cultivars funder nitrogen fertilization. There was a linear increase in leaf magnesium content in response to the addition of nitrogen fertilization for $\mathrm{cv}$. Pontal, with a maximum accumulated value of $6.3 \mathrm{~g} \mathrm{~kg}^{-1}$ under a dose of $200 \mathrm{~kg} \mathrm{ha}^{-1}$ nitrogen, and a minimum content of $3.7 \mathrm{~g} \mathrm{~kg}^{-1}$ in the control treatment. The $\mathrm{cv}$. Pérola obtained a maximum value of $5.5 \mathrm{~g} \mathrm{~kg}^{-1}$ at a dose of $50 \mathrm{~kg}$ ha ${ }^{1}$ nitrogen and a minimum content of $3.4 \mathrm{~g} \mathrm{~kg}^{-1}$ in the control (Fig 2C).

These results confirm the beneficial effect (synergism) of nitrogen fertilization to increase magnesium leaf content, which is in agreement with the report of Marschners (2012) on the relationship between these nutrients in plant nutrition. When comparing information from the literature (Martinez et al., 1999) on the adequate magnesium content found in bean leaves in full bloom, values of 3-6 $\mathrm{g} \mathrm{kg}^{-1}$ are found, and thus, the magnesium content obtained in the present situation, from3.4-6.3 $\mathrm{g} \mathrm{kg}^{-1}$, falls within this range.

The sulfur content was only signification relation to its accumulation in bean leaves, with cv. Pontal presenting a higher leaf content than cv. Pérola, at respective values of 1.7 and $1.5 \mathrm{~g} \mathrm{~kg}^{-1}$. However, it is necessary to emphasize that this difference is small and falls within the limits considered by Martinez et al. (1999) as suitable for the common bean $\left(1.5-2.0 \mathrm{~g} \mathrm{~kg}^{-1}\right)$.

There was no significant difference $(p<0.05)$ between leaf macronutrient levels in bean leaves in the evaluated cropping systems, with either intercropping or monoculture. 
Leaf micronutrient levels in castor bean intercropped with common bean subjected to different rates of nitrogen fertilization were not influenced by the treatments $(p<0.05)$, generally due to poor mobility or even the absence of micronutrients in the plant (Malavolta et al., 1997). Thus, the addition of nitrogen even at a higher than recommended dose (approximately $100 \mathrm{~kg} \mathrm{ha}^{-1}$ ) (Vieira, 2006) for common bean did not promote an increase or decrease in the micronutrient contents in response to fertilization, showing a certain equilibrium in fertilization demonstrated by the absence of symptoms of deficiency or toxicity of said micronutrients.

Suitable levels of boron, copper, iron, manganese and zinc for common bean crops (in mg kg ${ }^{-1}$ ) vary from 100-150, 8-10, 300-500, 200-300 and 45-55, respectively (Martinez et al., 1999). Thus, it can be affirmed that the average contents of the referenced micronutrients found in bean leaves intercropped with castor beans are close to these values since they were $114,6.8,119.3,103.4$ and $32.1 \mathrm{mg} \mathrm{kg}^{-1}$ for boron, copper, iron, manganese and zinc, respectively; therefore, there is no limitation on the growth/development of bean plants due to either micronutrient excess or deficiency. As observed for macronutrients, no significant difference $(p<0.05)$ was detected between the micronutrient levels in bean leaves under monoculture or intercropping.

The results for the nitrogen content in beans intercropped with castor beans were adjusted using a quadratic regression equation, where the highest value was found in cv. Paraguaçu (63 $\mathrm{g} \mathrm{kg}^{-1}$, with the use of $100 \mathrm{~kg} \mathrm{ha}^{-1}$ nitrogen) compared to the cultivar Energia, with a maximum content of $52 \mathrm{~g} \mathrm{~kg}^{-1}$ at the same dose (Fig 3A). On the other hand, the lowest leaf nitrogen contents, 41 and $33 \mathrm{~g} \mathrm{~kg}^{-1}$, were obtained in the treatments with the highest nitrogen dose (200 kg ha ${ }^{-1}$ ) for Paraguaçu and Energia, respectively, whose values were close to the controls, i.e., without fertilization. These results reflect the relevance of nitrogen fertilization for intercropping castor bean crops.

The magnesium and nitrogen contents in the leaves of intercropped beans were influenced $(p<0.05)$ by the nitrogen fertilization. Those of the cv. Paraguaçu was adjusted using a linear equation with a maximum magnesium accumulation of $2.82 \mathrm{~g} \mathrm{~kg}^{-1}$ at the highest nitrogen dose evaluated. For the cultivar Energia, the maximum leaf magnesium content was obtained $\left(2.77 \mathrm{~g} \mathrm{~kg}^{-1}\right)$ at a nitrogen dose of $50 \mathrm{~kg} \mathrm{ha}^{-1}$ under cover (Fig 3B). The increase in the leaf magnesium content in response to nitrogen fertilization is justified by the occurrence of a synergistic effect between nitrogen and magnesium, as reported by Marschner (2012), which was also found for the common bean.

With the exception of foliar nitrogen and magnesium contents, even with the addition of high nitrogen doses via fertilization (higher than $100 \mathrm{~kg} \mathrm{ha}^{-1}$ ), there was no increase or decrease in the foliar content of other nutrients in castor bean leaves by means of regulatory processes. Plants can exhibit synergism or antagonism (Marschner, 2012), demonstrating a good balance of the nutrients supplied to the castor bean crop.

In the leaf analysis of castor beans intercropped with beans, the average levels of nitrogen, phosphorus, potassium, calcium, magnesium and sulfur were 47.1, 3.4, 30.4, 16.4, 3.6 and $3.1 \mathrm{~g} \mathrm{~kg}^{-1}$, respectively. According to Martinez et al. (1999), suitable macronutrient levels found in castor bean leaves (in $\mathrm{g} \mathrm{kg}^{-1}$ ) in full bloom are $\mathrm{N}=40-50 ; \mathrm{P}=3-4 ; \mathrm{K}=30$ 40; $\mathrm{Ca}=15-25 ; \mathrm{Mg}=3-4$ and $\mathrm{S}=3-4$. Thus, the contents of said macronutrients in castor bean leaves in the present situation are within the limits considered suitable for good growth/development of intercropped castor bean plants. There was no significant difference $(p<0.05)$ in the accumulation of macronutrients in castor leaves in the two studied systems (intercropping and monoculture).

The manganese content in the leaf tissue of the beans intercropped with castor showed a linear increase with nitrogen fertilization, obtaining a maximum value $(175 \mathrm{mg}$ $\left.\mathrm{kg}^{-1}\right)$ at the highest dose $\left(200 \mathrm{~kg} \mathrm{ha}^{-1}\right)$ and minimum value (123 mg kg $\mathrm{mg}^{-1}$ in the control (Fig 4), demonstrating the synergistic effect of nitrogen fertilization in relation to manganese uptake by plants and thus corroborating reports by Marschner (2012).

The average leaf contents of boron, copper, iron, manganese and zinc micronutrients in intercropped castor beans were $132,7,120,145$ and $25 \mathrm{mg} \mathrm{kg}^{-1}$. It was also verified that there were no significant differences $(p<0.05)$ between the castor bean leaf contents of accumulated micronutrients in the intercropping and monoculture systems.

\section{Agronomic characteristics of common bean and castor bean}

Among the evaluated components, the number of pods per plant was significantly influenced $(p<0.05)$ by the interaction of bean cultivars under intercropping and nitrogen treatments. The cv. Pontal presented a maximum value of 11 pods per plant, with a dose of $100 \mathrm{~kg} \mathrm{ha}^{-1}$ nitrogen, compared to $\mathrm{cv}$. Pérola, for which the largest number of pods per plant (8) was obtained at the same dose of nitrogen (Fig 5). In both cases, the lowest values of the number of pods per plant were verified in the control, showing the importance of nitrogen fertilization added to the bean plants, regardless of the genetic material used. It is noteworthy that in most studies involving bean crops this has been the yield component most closely related to grain yield (Andrade et al., 2001) and is directly influenced by environmental conditions (Oliveira et al., 2009).

The number of grains per pod and weight of one hundred grains were not influenced $(p<0.05)$ by the treatments, which is expected because these are characteristics with a strong genetic influence, justifying a lack of response to nitrogen fertilization.

The grain yield of common bean intercropped with castor bean was significantly influenced $(p<0.05)$ by the interaction of cultivars and nitrogen treatments, confirming the result obtained for the component number of grains per pod. There was a quadratic effect of nitrogen treatments, with the highest grain yields of 1,122 and 1,024 kg ha ${ }^{-1}$ for the cvs. Pontal and Pérola of common bean both obtained with the dose of $100 \mathrm{~kg} \mathrm{ha}^{-1}$ of nitrogen under cover. In contrast, the lowest levels of intercropped bean yield were obtained with the two cultivars studied, with grain yields of 549 and $546 \mathrm{~kg}$ $\mathrm{ha}^{-1}$ for Pontal and Pérola cvs, respectively (Fig 6).

The yield of intercropped bean crop is below that normally obtained under monoculture in the Midwest region, where it is common to obtain yields above $1,500 \mathrm{~kg} \mathrm{ha}^{-1}$. However, under intercropping, where common beans are considered secondary to castor beans (main crop), its yield is reduced by $50 \%$, compared to that in the monoculture system (Vieira, 2006). The average number of pods was 11.6 under intercropping and 15.8 under monoculture, while the average grain yields were $835 \mathrm{~kg} \mathrm{ha}^{-1}$ and 1,293 $\mathrm{kg} \mathrm{ha}^{-1}$, respectively. 
Table 1. Coefficients of the linear and nonlinear regression models adjusted for the variables evaluated.

\begin{tabular}{|c|c|c|c|c|c|c|}
\hline Crops & Variable & Cultivar & $\beta_{0}$ & $\beta_{1}$ & $\beta_{2}$ & $\mathrm{R}^{2}$ \\
\hline \multirow{13}{*}{ Common bea } & $\mathrm{N}$ content & - & 34.779 & $0.048^{+}$ & $-0.0002^{+}$ & $0.91^{*}$ \\
\hline & \multirow{2}{*}{ K content } & Pontal & 17.538 & $0.024^{+}$ & $-0.0001^{+}$ & $0.83^{*}$ \\
\hline & & Pérola & 17.164 & $0.006^{+}$ & - & $0.80^{*}$ \\
\hline & \multirow{2}{*}{ Ca content } & Pontal & 35.180 & $0.067^{+}$ & $-0.0003^{+}$ & $0.89^{*}$ \\
\hline & & Pérola & 34.637 & $-0.036^{+}$ & - & $0.90^{*}$ \\
\hline & & & & & & \\
\hline & \multirow{3}{*}{ Mg content } & Pontal & 4.000 & $0.012^{+}$ & - & $0.94^{*}$ \\
\hline & & Pérola & 3.571 & $0.036^{+}$ & $-0.0002^{+}$ & $0.80^{*}$ \\
\hline & & & & & 0 & \\
\hline & \multirow{2}{*}{ Number of pods per plant } & Pontal & 6.792 & $0.077^{+}$ & $-0.0004^{+}$ & $0.99^{*}$ \\
\hline & & Pérola & 5.469 & $0.044^{+}$ & $-0.0002^{+}$ & $0.99^{*}$ \\
\hline & \multirow{2}{*}{ Grain yield } & Pontal & 510.320 & $8.356^{+}$ & $-0.0302^{+}$ & $0.90^{*}$ \\
\hline & & Pérola & 504.750 & $7.584^{+}$ & $-0.0296^{+}$ & $0.92^{*}$ \\
\hline \multirow{11}{*}{ Castor bean } & \multirow[t]{2}{*}{$\mathrm{N}$ content } & Paraguaçu & 41.253 & $0.387^{+}$ & $-0.0019^{+}$ & $0.95^{*}$ \\
\hline & & Energia & 36.428 & $0.281^{+}$ & $-0.0015^{+}$ & $0.89^{*}$ \\
\hline & \multirow[t]{2}{*}{ Mg content } & Paraguaçu & 2.572 & $0.001^{+}$ & - & $0.92^{*}$ \\
\hline & & Energia & 2.676 & $0.002^{+}$ & $-0.00001^{+}$ & $0.86^{*}$ \\
\hline & Mn content & - & 122.400 & $0.271^{+}$ & - & $0.99^{*}$ \\
\hline & \multirow{2}{*}{$\begin{array}{l}\text { Number of bunches per } \\
\text { plant }\end{array}$} & Paraguaçu & 19.225 & $0.289^{+}$ & $-0.0013^{+}$ & $0.89^{*}$ \\
\hline & & Energia & 17.956 & $0.155^{+}$ & $-0.00007^{+}$ & $0.93^{*}$ \\
\hline & \multirow{2}{*}{$\begin{array}{l}\text { Number of berries per } \\
\text { bunch }\end{array}$} & Paraguaçu & 22.575 & $0.107^{+}$ & $-0.0005^{+}$ & $0.98^{*}$ \\
\hline & & Energia & 31.577 & $0.068^{+}$ & $-0.0004^{+}$ & $0.82^{*}$ \\
\hline & \multirow{2}{*}{ Grain yield } & Paraguaçu & 1080.900 & $6.803^{+}$ & $-0.0346^{+}$ & $0.90^{*}$ \\
\hline & & Energia & 785.990 & $8.613^{+}$ & $-0.0404^{+}$ & $0.96^{*}$ \\
\hline
\end{tabular}

${ }^{+}$Significant at $5 \%$ probability by $\mathrm{t}$ test; " Significant at $5 \%$ probability by $\mathrm{F}$ test.

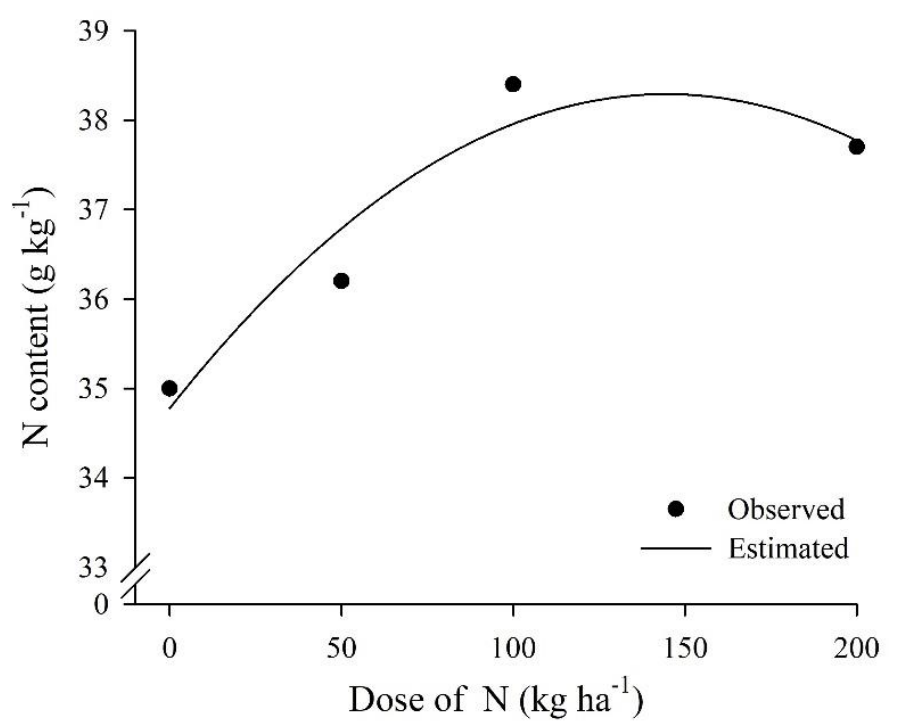

Fig 1. The average leaf nitrogen content in common beans intercropped with castor beans subjected to different doses of nitrogen coverage. 

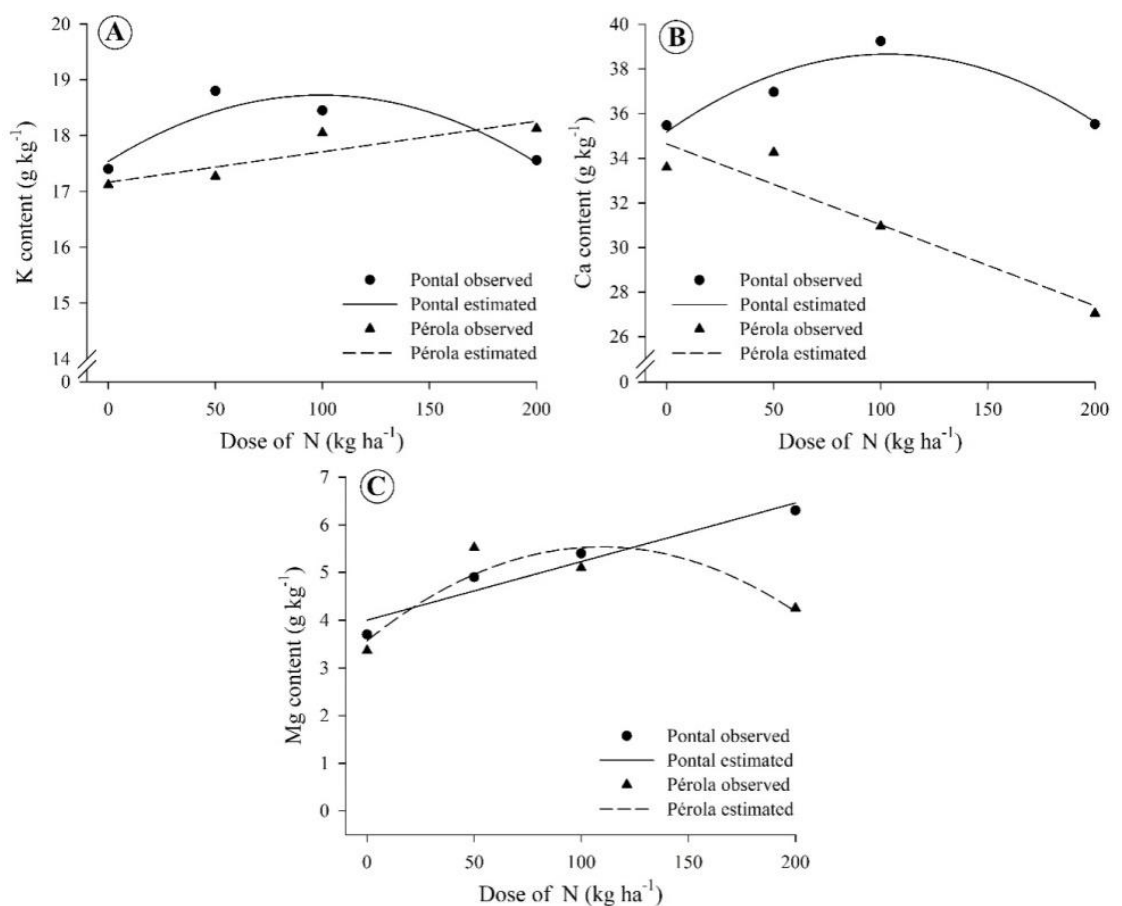

Fig 2. The average leaf contents of potassium (A), calcium (B) and magnesium (C) in common bean intercropped with castor bean cultivars subjected to different doses of nitrogen fertilization.
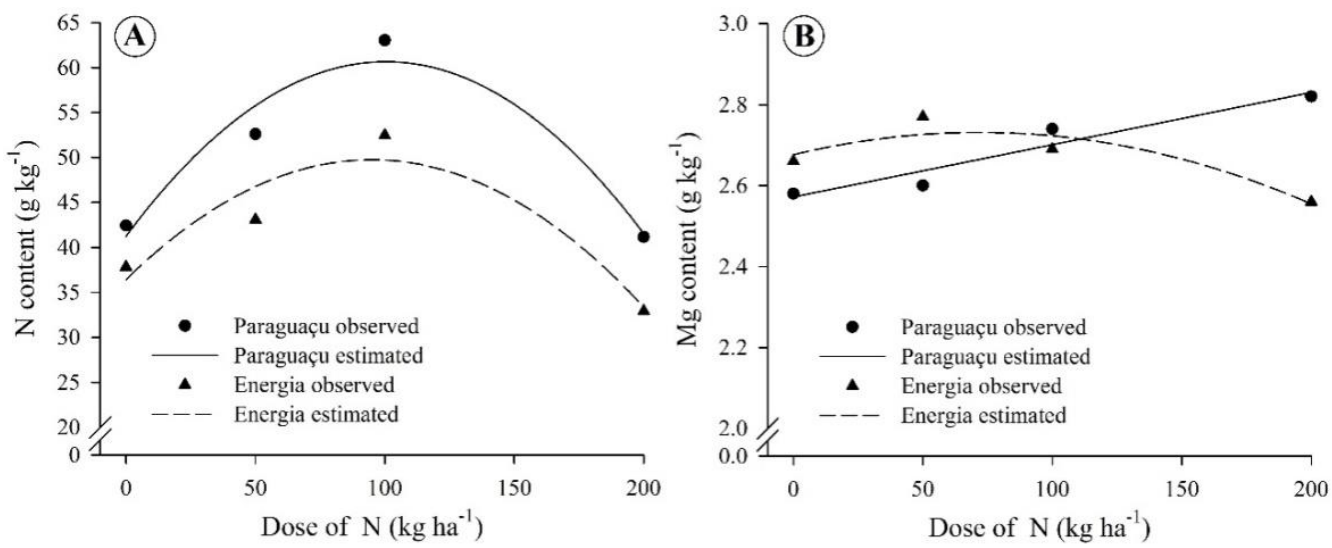

Fig 3. The average leaf contents of nitrogen $(A)$ and magnesium (B) in castor beans intercropped with common beans subjected to different doses of nitrogen fertilization.

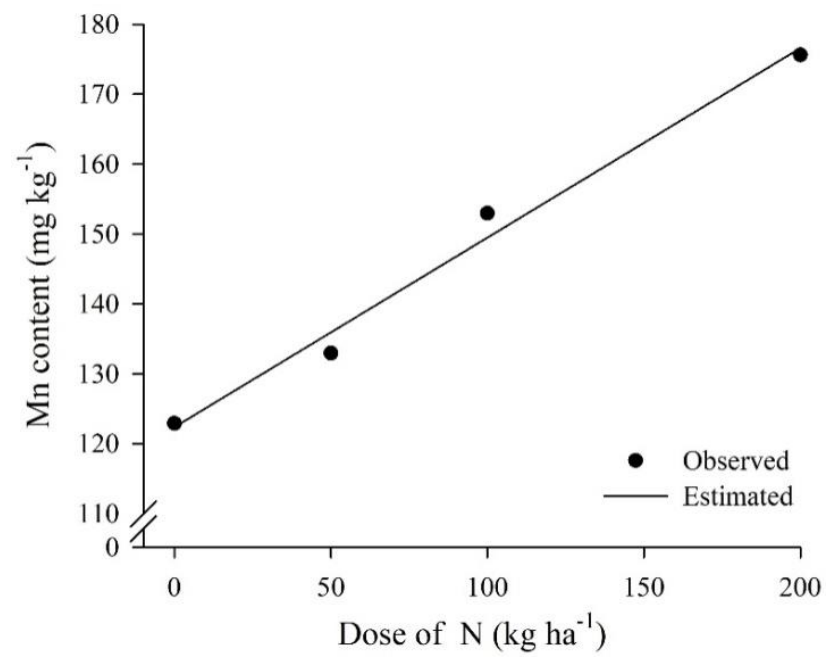

Fig 4. The average leaf content of manganese in castor beans intercropped with common beans subjected to different doses of nitrogen fertilization. 


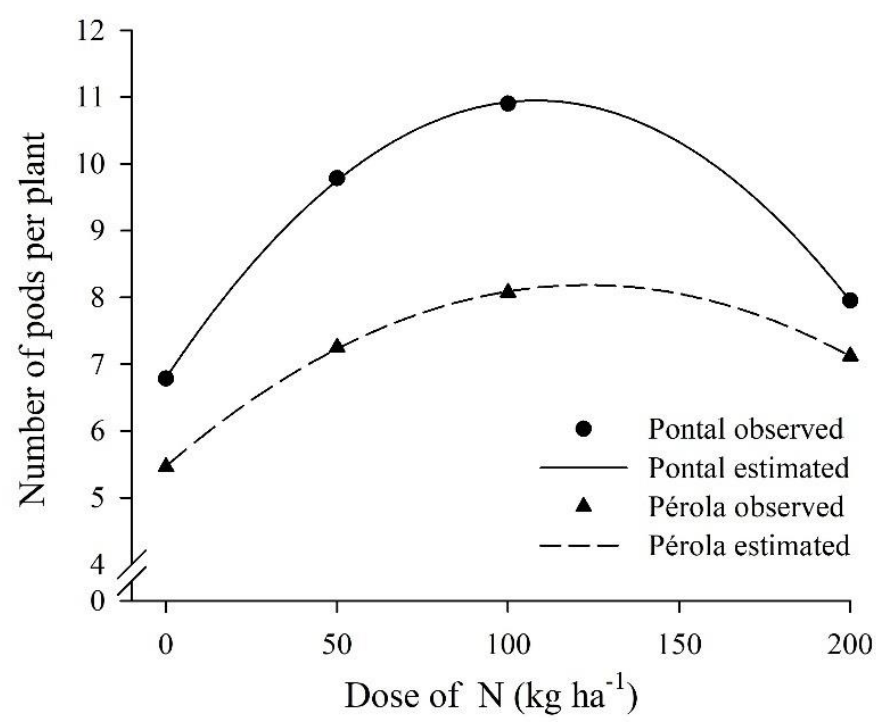

Fig 5. The number of pods per plant of common bean intercropped with castor beans, subjected to different doses of nitrogen fertilization.

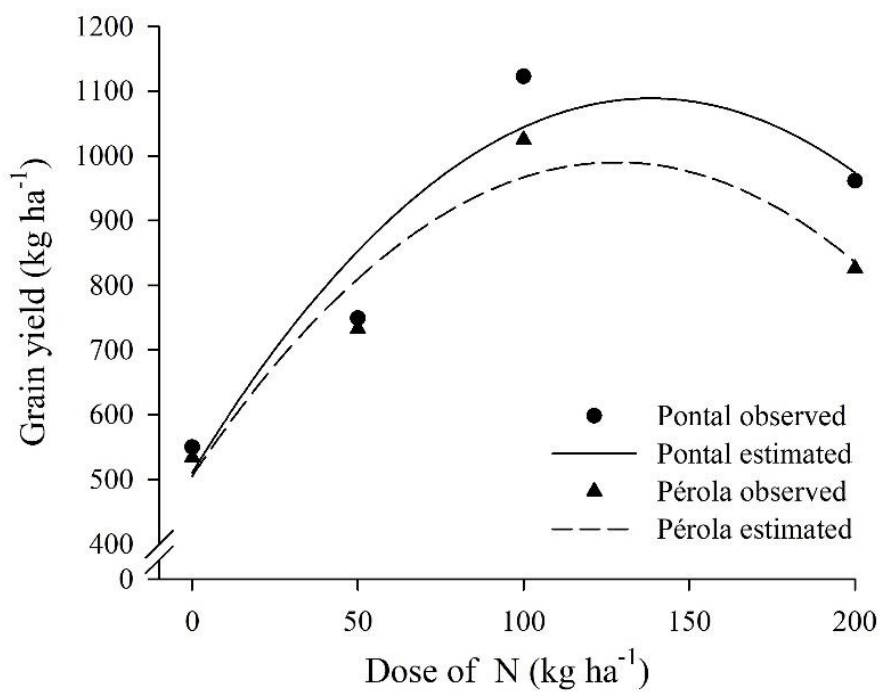

Fig 6. The grain yield of common bean intercropped with castor beans subjected to different doses of nitrogen fertilization.

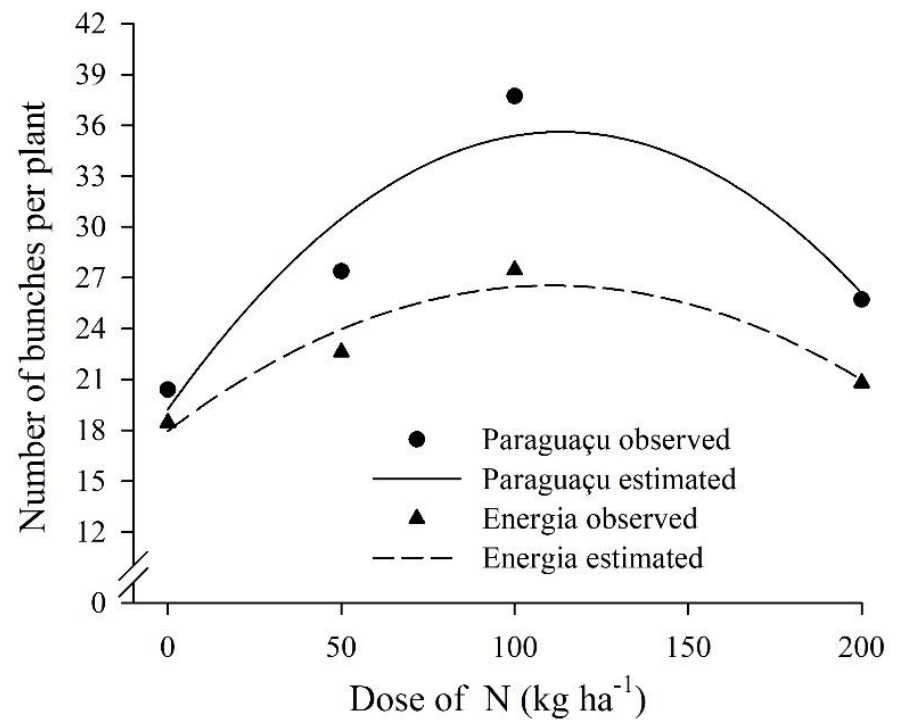

Fig 7. The number of bunches per plant of castor bean intercropped with common bean subjected to different doses of nitrogen fertilization. 


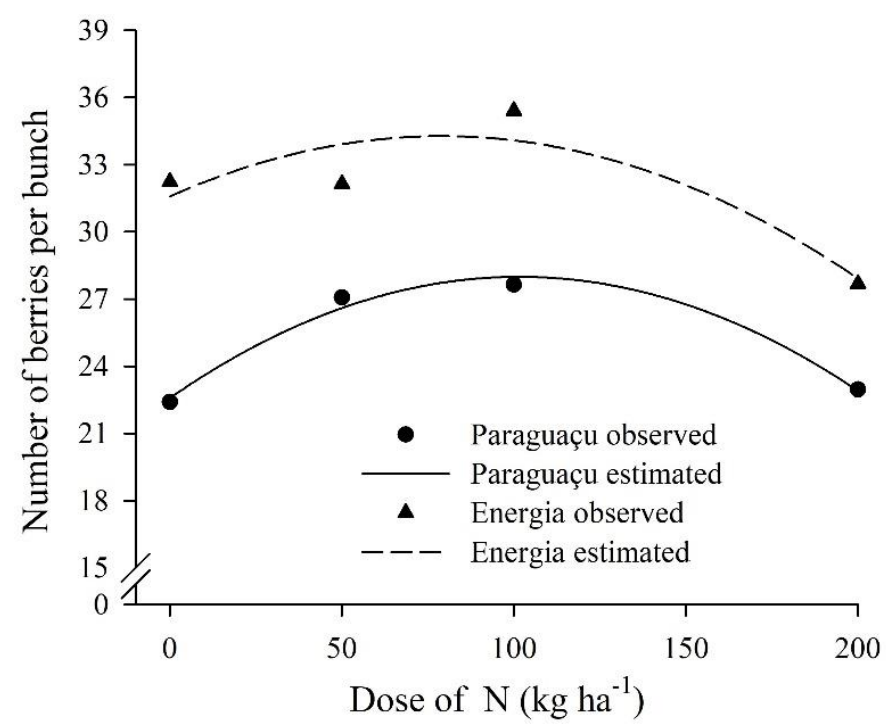

Fig 8. The number of berries per bunch of castor beans intercropped with common beans, subjected to different doses of nitrogen coverage.

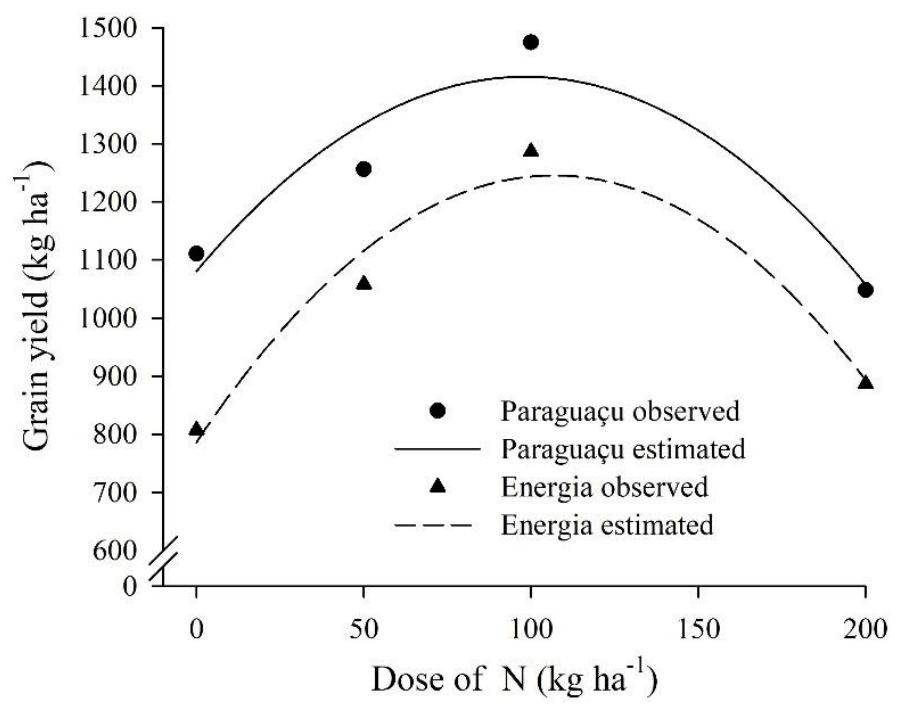

Fig 9. The grain yield of castor beans intercropped with common beans, subjected to different doses of nitrogen coverage.

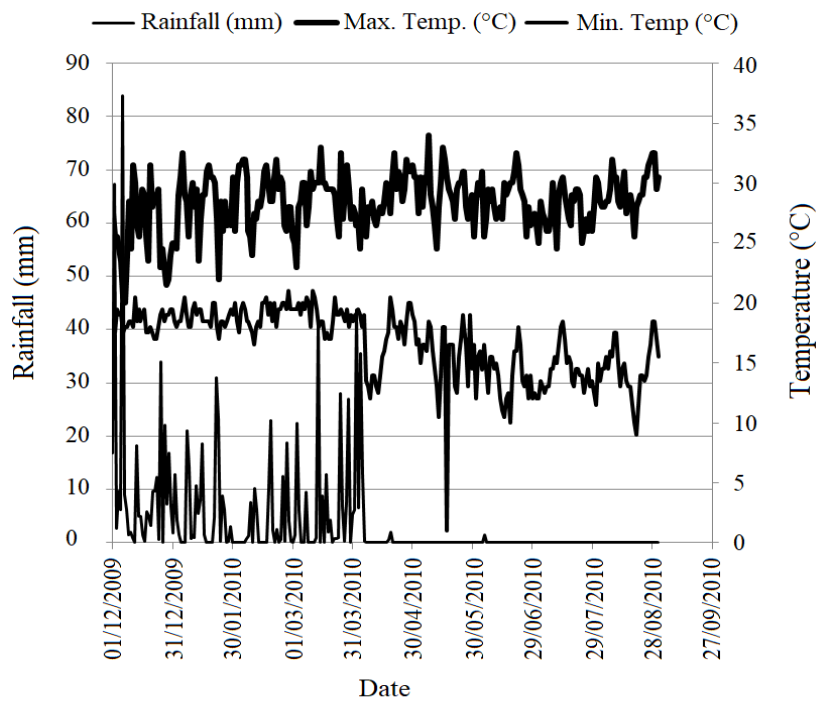

Fig 10. Daily climatic data for the period from sowing to harvest (December 2009 to August 2010). Data provided by INMET (Instituto Nacional de Meteorologia - GO - Brazil. 
The main advantage of intercropping is the existence of two or more crops in the same area, whose yields per unit area are higher than those for monoculture (Vieira, 2006), corroborated especially by the result of the number of pods per plant, thus ensuring a higher return to producers according to the report by Teixeira et al. (2005).

The cv. Paraguaçu produced a higher number of bunches per plant compared to cv. Energia, with a maximum value of 38 obtained with the use of $100 \mathrm{~kg} \mathrm{ha}^{-1}$ nitrogen, while Energia presented 27 bunches per plant at the same dose (Fig 7). This difference between the referred genotypes can be attributed to the plant growth potential, such as in the case of cv. Paraguaçu, whose size can reach up to $1.6 \mathrm{~m}$ (Embrapa, 2012), with greater branching of plagiotropic bunches. However, in the present situation, the cv. Paraguaçu reached up to $4.0 \mathrm{~m}$ in the highest nitrogen treatments, with great difficulty in harvesting. However, for both cvs. Paraguaçu and Energia, there was a decrease in the number of bunches per plant, evidencing the effect of nitrogen fertilization toxicity for both cultivars at higher dosages. These results are in disagreement with Silva et al. (2007), who verified that the number of bunches per plant was not altered by nitrogen fertilization under monoculture conditions.

The number of berries per bunch was adjusted with a quadratic behavior regression equation, with a significant effect $(p<0.0 .5)$ of the interaction of cultivar factors and rates of nitrogen fertilization. The cv. Energia produced presented higher values of berries per bunch (35.4) at the rate of $100 \mathrm{~kg} \mathrm{ha}^{-1}$, while cv. Paraguaçu presented a lower number of berries per bunch (27.6) at the same dose of nitrogen (Fig 8). The sharp drop evidenced from these doses confirms the occurrence of nitrogen fertilization toxicity when higher than $100 \mathrm{~kg} \mathrm{ha}^{-1}$. The different behavior of the cvs. Energia and Paraguaçu is justified by the genetics of the plants; the cultivar Energia produces bunches with a higher number of berries but with a lower weight.

The yield of castor bean intercropped with common bean was influenced by the double cultivar and nitrogen dose interactions $(p<0.05)$, and the regression equation with quadratic behavior was adjusted for the two genetic materials used. The highest grain yield was obtained from cv. Paraguaçu, which had the maximum value of $1,474 \mathrm{~kg} \mathrm{ha}^{-1}$ under $100 \mathrm{~kg} \mathrm{ha}^{-1}$ nitrogen, compared to cv. Energia, whose highest yield was $1,286 \mathrm{~kg} \mathrm{ha}^{-1}$ at the same dose (Fig 9). Thus, it can be said that above these nitrogen doses mentioned above, there are decreases in castor bean yield for both genotypes studied. In work conducted by Silva et al. (2007), the productivity of castor bean hybrid Sara was also adjusted to the second degree equation, whose maximum point was obtained by applying $80 \mathrm{~kg} \mathrm{ha}^{-1}$ of nitrogen and was therefore close to the dosages obtained here. For an average weight of one hundred grains, an effect was detected $(p<0.05)$ only on the cultivar factor, with Paraguaçu producing higher weight seeds (75 g) than Energia (43 g), regardless of nitrogen fertilization. The detection of this difference in the statistical analysis was expected because it is an intrinsic characteristic of the material; that is, it is a genetic characteristic. The average weights of 100 grains verified for the cvs. Energia and Paraguaçu, cited above, are close to the literature values, which according to Embrapa (2012) are 40-53 and 71 $\mathrm{g}$, respectively.

Based on the average castor bean yield of some cultivars of the IAC, which ranges from 1,500 to $2,000 \mathrm{~kg} \mathrm{ha}^{-1}$ (Savi Filho, 1998), it is observed that the maximum yields for cvs.
Paraguaçu and Energia obtained by intercropping with common beans are close to the levels obtained under monoculture and in the absence of nutrient deficiency problems. Regarding the average yield of castor beans 1,222 and 1,009 $\mathrm{kg} \mathrm{ha}^{-1}$, respectively, for Paraguaçu and Energia under intercropping with beans, it can be said that this was practically twice the national average of this oilseed $\left(631 \mathrm{~kg} \mathrm{ha}^{-1}\right.$ of the $2017 / 18$ crop (Conab, 2019) under monoculture that is, the crops considered secondary beans did not cause any damage to the castor bean production. It is worth remembering that in this case, the common bean crop is considered an extra product of the activity, according to Vieira (2006), which provides more financial gains to producers. Moreover, it can be said that the nitrogen fertilization in cover, when added in adequate dosages, proved to be a great tool for productivity increase for beans intercropped with castor bean crops.

\section{Materials and Methods}

\section{Plant materials}

The experiment was conducted in the 2010/2011 "waters" harvest at the Emater Experimental Station based in the municipality of Anápolis-GO, Brazil, whose geographical coordinates are $16^{\circ} 19^{\prime} 31^{\prime \prime} \mathrm{S}$ and $48^{\circ} 58^{\prime} 3{ }^{\prime \prime} \mathrm{W}$, with a $1,000-\mathrm{m}$ altitude, an average annual temperature of $22.3^{\circ} \mathrm{C}$ and an average annual rainfall of $1,610 \mathrm{~mm}$. The climate classification of the site according to Köppen, is Aw and presents mesoclimatic characteristics of a semi-humid tropical rainfall, with a well-defined dry season and warm thermal regime (Nimer, 1979).

Climate data for rainfall, temperature, and relative humidity from December 2009 to August 2010 are presented below (Fig 10). This period corresponds to the beginning of sowing and lasts until the last harvest of the castor bean - a longercycle crop, with a longer time in the field.

Soil samples classified as Yellow Red Latosol were distributed in the $0-20 \mathrm{~cm}$ layer and sent to the laboratory for chemical and physical analysis. The results were as follows: $\mathrm{pH}\left(\mathrm{H}_{2} \mathrm{O}\right)=6.3 ; \mathrm{P}\left(\mathrm{mg} \mathrm{dm}^{-3}\right)=2.2 ; \mathrm{K}^{+}\left(\mathrm{cmol}_{\mathrm{c}} \mathrm{dm}^{-3}\right)=$ 7.5; $\mathrm{Ca}^{2+}\left(\mathrm{cmol}_{\mathrm{c}} \mathrm{dm}^{-3}\right)=4.3 ; \mathrm{Mg}^{2+}\left(\mathrm{cmol}_{\mathrm{c}} \mathrm{dm}^{-3}\right)=1.3 ; \mathrm{Al}^{3+}$ $\left(\mathrm{cmol}_{\mathrm{c}} \mathrm{dm}^{-3}\right)=0.2 ; \mathrm{H}^{+} \mathrm{Al}^{3+}\left(\mathrm{cmol}^{\mathrm{C}} \mathrm{dm}^{-3}\right)=5.2 ; \mathrm{m}(\%)=0.3 ; \mathrm{V}$ $(\%)=63 ; \mathrm{B}\left(\mathrm{mg} \mathrm{dm}^{-3}\right)=0.5 ; \mathrm{Cu}\left(\mathrm{mg} \mathrm{dm}^{-3}\right)=1.7 ; \mathrm{Fe}\left(\mathrm{mg} \mathrm{dm}^{-3}\right)$ $=163.0 ; \mathrm{Mn}\left(\mathrm{mg} \mathrm{dm}^{-3}\right)=14.5 ; \mathrm{Zn}\left(\mathrm{mg} \mathrm{dm}^{-3}\right)=2.7$; organic carbon $\left(\mathrm{g} \mathrm{kg}^{-1}\right)=20$; sand $\left(\mathrm{g} \mathrm{kg}^{-1}\right)=330$; silt $\left(\mathrm{g} \mathrm{kg}^{-1}\right)=165$ and clay $\left(\mathrm{g} \mathrm{kg}^{-1}\right)=505$.

\section{Experimental design and treatments}

A randomized complete block design was used in a $2 \times 2 \times 4+$ 4 factorial scheme with three replications. The treatments consisted of two bean cultivars (Pontal and Pérola) intercropped with two castor bean cultivars (Energia and Paraguaçu), submitted to four nitrogen treatments, applied as crop cover $\left(0,50,100\right.$ and $\left.200 \mathrm{~kg} \mathrm{ha}^{-1}\right)$. Four additional treatments involved bean and castor bean cultivars at a single dose of $40 \mathrm{~kg} \mathrm{ha}^{-1}$ nitrogen, as recommended by the literature for both crops (Chagas et al., 1999; CFSEMG, 1999).

\section{Implementation and conduction}

The castor bean plots consisted of four rows, $5.0 \mathrm{~m}$ long and $3.0 \mathrm{~m}$ apart. Five rows of beans were placed between the lines of the castor beans, obeying the spacing of 0.5 
between them. The useful area was taken to be the two central lines of each plot.

Soil tillage was carried out in a conventional manner, with one plow and two harrows. The basic fertilization was performed using the formulation 05-25-15 at a dose of 400 $\mathrm{kg} \mathrm{ha}{ }^{-1}$. Castor bean and common bean sowing were performed simultaneously and manually within the row furrows, using $25 \%$ more seeds. $10 \mathrm{DAE}$, the plants were thinned with the aim of reaching castor bean and bean densities of 1 and 12 plants per linear meter, respectively. At $25 \mathrm{DAE}, \mathrm{N}$ fertilization was performed in continuous fillets along the lines, with urea as the source, according to the treatments applied.

Post emergence weed control was performed during the crop cycle by means of hoe and chemical control, using the commercial mixture of fomesafen + fluazifop-p-butyl herbicides, with a dose of $1.0 \mathrm{~L} \mathrm{ha}^{-1}$ at 20 and $30 \mathrm{DAE}$. Two applications of procymidone fungicide at $1.0 \mathrm{~kg} \mathrm{ha}^{-1}$ were applied to control gray mold (Amphobotrys ricini) in the castor bean crop and anthracnose (Colletotrichum lindemuthianum) and angular leaf spot (Phaeoisariopsis griseola) in the common bean. The insecticide deltamethrin was used to control leafhoppers (Empoasca kraemeri) at a dosage of $50 \mathrm{~mL} \mathrm{ha}^{-1}$.

\section{Parameters analyzed}

At the time of full flowering, 10 leaves and 20 trifolium of castor bean and common bean, respectively, were collected from the crops involved in the study in the useful area of each plot. The collection of trifolium in the bean was performed in the middle third of the plant. The leaves were placed in perforated paper bags and placed in a greenhouse at $72^{\circ} \mathrm{C}$ until maintaining a constant weight. Subsequently, the materials were analyzed for leaf contents of $\mathrm{N}, \mathrm{P}, \mathrm{K}, \mathrm{Ca}$, $\mathrm{Mg}, \mathrm{B}, \mathrm{Cu}, \mathrm{Fe}, \mathrm{Mn}$ and $\mathrm{Zn}$, according to the methodology described by Malavolta et al. (1997).

At maturity, the bean yield and its components (number of pods per plant, number of grains per pod and mass of 100 grains) were evaluated. In the castor bean crop, the yield of berries and its components (number of bunch/plant, number of berries/bunch and mass of 100 grains) were quantified, as well as the final stand, plant height and stem diameter.

\section{Statistical analysis}

Data were subjected to analysis of variance, and means of qualitative factor (cultivars) were compared using the Tukey test at $5 \%$ probability. The quantitative factor (nitrogen doses) was studied by regression analysis. The statistical analyses were performed using Sisvar Version 5.3 software (Build 7).

\section{Conclusions}

Nitrogen, potassium, calcium, magnesium and sulfur leaf contents in common bean plants intercropped with castor bean were influenced $(p<0.05)$ by nitrogen treatments. For castor beans, the effect of treatments $(p<0.05)$ on leaf contents of nitrogen, magnesium and sulfur in common bean intercropping was verified. There was no significant difference $(p<0.05)$ between the intercropping and monoculture systems regarding bean and castor bean plant nutrition.
For common bean, the maximum grain yields were 1,122 and $1,024 \mathrm{~kg} \mathrm{ha}^{-1}$ for Pontal and Pérola, respectively, with a dose of $100 \mathrm{~kg} \mathrm{ha}^{-1}$ of nitrogen under cover. Similar results were observed for castor bean, whose dose of $100 \mathrm{~kg} \mathrm{ha}^{-1}$ provided the largest number of bunches, number of berries per bunch and the highest grain yield.

The maximum values observed were 38 and 27 bunches per plant, 27.6 and 35.4 berries per bunch and 1,474 and 1,286 $\mathrm{kg} \mathrm{ha}{ }^{-1}$ of grain yield for cvs. Paraguaçu and energy, respectively.

\section{Acknowledgment}

To CNPq (Conselho Nacional de Desenvolvimento Científico e Tecnológico, Brazil), for funding the research (Process: 482631/2009-0) and granting a productivity grant to the sixth author.

\section{References}

Andrade CAB, Patroni SMS, Clemente E, Scapim CA (2004) Produtividade e qualidade nutricional de cultivares de feijão em diferentes adubações. Cienc Agrotec. 28:10771086.

Andrade MJB, Moraes AR, Teixeira IR, Silva MV (2001) Avaliação de sistemas de consórcio de feijão com milhopipoca. Cienc Agrotec. 25:242-250.

Campos ESC, Santos VML (2015) Estudo do processo de extração de óleo de mamona em cooperativas do pólo São Francisco. Engevista. 17:477-490.

Cardoso FR, Galante AHA, Teixeira IR, Silva AG, Reis EF (2013) Fontes e doses de zinco na nutrição e produção de feijão-comum e mamona em consórcio. Agrária. 8:602609, 2013.

Cfsemg - Comissão e Fertilidade do Solo do Estado de Minas Gerais (1999) Mamona. In: Ribeiro, A.C., Guimarães, P.T.G., Alvares V., V.H. Recomendações para o uso de corretivos e fertilizantes em Minas Gerais - 50 Aproximação. Viçosa: Cfsemg, p.311.

Chagas JM, Braga JM, Vieira C, Salgado LT, Junqueira Neto A, Araújo GAA, Andrade MJB, Lana RMQ, Ribeiro AC (1999). Feijão. In: Ribeiro AC, Guimarães PTG, Alvarez VVH. Recomendações para o uso de corretivos e fertilizantes em Minas Gerais. 5o. Aproximação. Viçosa: CFSEMG. p.306309.

Conab - Companhia Nacional de Abastecimento (2019) Acompanhamento da safra brasileira: grãos safra 2018/19 - 12a levantamento. Setembro de 2019. Available $<$ <ttp://www.conab.gov.br>. Acessed 12 Set. 2019.

Conab - Companhia Nacional de Abastecimento (2019) Safras: série histórica (mamona). Available < Boletins grão maio - resumo 2019.pdf Boletim de grãos completo - maio 2019 Tabela de Levantamento>. Acessed 03 jun. 2019.

Cunha DA, Teixeira IR, Jesus FF, Souza RTG, Teixeira GCS (2014) Adubação fosfatada e produção de feijão-comum e mamona em consórcio. Biosc J. 30: 617-628.

EMBRAPA - Empresa Brasileira de Pesquisa Agropecuária (2012) Mamona: cultivares. Available <http://www.cnpa.embrapa.br/produtos/mamona/cultiva res.html.>. Acessed 17 Jul. 2019.

Fan XH, Li YC (2010) Nitrogen release from slow-release fertilizers as affect by soil type and temperature. Soil Sci Soc Am J. 74:1635-1641. 
Ferreira RB, Teixeira IR, Reis EF, Teixeira GCS, Silva AG (2014) Management of top-dressed nitrogen fertilization in the common bean/castor intercropping system. Aust J Crop Sci. 8:1086-1092.

Gebru H (2015) A review on the comparative advantage of intercropping systems. J Biology, Agric Healthcare. 5:28-38. Goneli ALD, Corrêa PC, Oliveira APLR, Hartmann Filho CP Oba GC (2018) Castor beans quality subjected to different storage temperatures and periods. Eng Agri. 38: 631-638.

Huber DM, Thompson LA (2007) Nitrogen and plant disease. In: Datnoff LE, Elmer WH, Huber DM. Mineral nutrition and plant disease. Washington: The American Phytopathological Society Press, p.31-44.

Lange A, Martinez AM, Silva MAC, Sorreano MCM, Cabral CP, Malavolta E (2005) Efeito de deficiência de micronutrientes no estado nutricional da mamoneira cultivar Íris. PesquiAgropecu Bras. 40:61-67.

Lima RLS, Severino LS, Albuquerque RC, Beltrão NEM, Sampaio LR (2008) Casca e torta de mamona avaliados em vasos com fertilizantes orgânicos. Rev Caatinga 21:102-106.

Malavolta E, Vitti GC, Oliveira SA (1997) Avaliação do estado nutricional das plantas: princípios e aplicações. 2. ed., Piracicaba: Potafós, 319p.

Marschner H (2012) Mineral nutrition of higher plants. 3.ed London: Elsevier, 643p.

Martinez HEP, Carvalho JG, Souza RB (1999) Diagnose foliar. In: Ribeiro AC, Guimarães PTG, Alvarez VVH (Ed.) (1999) Recomendação para o uso de corretivos e fertilizantes em Minas Gerais. Viçosa: Comissão de Fertilidade do Estado de Minas Gerais. p.143-168.

Mateus GP, Crusciol CAC, Borghi E, Hirata ACS, Araújo HS (2015) Adubação nitrogenada em cultivares de mamona no sistema de semeadura direta consolidada. Magistra. 27: 460-467.

Mengel K, Kirkby EA (2001) Principles of plant nutrition. Netherlands: Springer, 849p.

Mohamed MH, Mursy HM (2015) Improving quantity and quality of castor bean oil for biofuel growing under severe conditions in Egypt. Energy Proced. 68:117-121.
Monteiro LA, Pianovski Júnior $G$, Velásquez JA, Rocha $D$, Bueno AV (2013) Performance impact of the application of castor oil biodiesel in diesel engines. Eng Agri. 33:11651171.

Moro A, Crusciol CAC, Carvalho LLT (2011) Épocas de aplicação de nitrogênio para híbridos de mamona no sistema plantio direto em safrinha. Semina: Ciênc Agrár. 32: 391-410.

Nimer E (1979) Climatologia do Brasil. Rio de Janeiro: IBGE. 421p.

Oliveira RL, Muniz JA, Andrade MJB, Reis RL (2009) Precisão experimental em ensaios com a cultura do feijão. Cienc Agrotec. 33:113-119.

Savi Filho A (1998) Mamona. In: Fahl Jl, Camargo MBP, Pizzinatto MA, Betti JA, Melo AMT, Demaria IC, Furlani ANC. Instruções agrícolas para as principais culturas econômicas. 6.ed. Campinas: IAC, 396p. (Boletim técnico, 200).

Severino LS, Ferreira GB, Moraes CRA, Gondim TMS, Cardoso GD, Viriato JR, Beltrão NER (2006b) Produtividade e crescimento da mamoneira em resposta à adubação orgânica e mineral. Pesqui Agropecu Bras. 41:879-882.

Severino LS, Ferreira GB, Moraes CRA, Gondim TMS, Freire WSA, Castro DA, Cardoso GD, Beltrão NER (2006a) Crescimento e produtividade da mamoneira adubada com macronutriente e micronutriente. Pesqui Agropecu Bras. 41:563-568.

Silva TRB, Leite VE, Silva ARB, Viana LH (2007) Adubação nitrogenada em cobertura na cultura da mamona em plantio direto. Pesqui Agropecu Bras 42:1357-1359.

Teixeira IR, Mota JH, Silva AG (2005) Consórcio de hortáliças. Semina: Ciênc Agrár. 24:507-514.

Trenkel ME (2010) Slow and controlled-release and stabilized fertilizers: An option for enhancing nutrient use efficiency in agriculture. International Fertilizer Industry Association. Paris, 167p.

Vieira C (2006) Cultivos consorciados. In: Vieira C, Paula Júnior TJ, Borém A. Feijão. 2 ed., Viçosa: UFV, p. 493-528. 